\title{
Remotely sensed mesoscale oceanography of the Central Eastern Pacific and recruitment variability in Dosidicus gigas
}

\author{
Claire M. Waluda*, Paul G. Rodhouse \\ British Antarctic Survey, Natural Environment Research Council, High Cross, Madingley Road, Cambridge CB3 0ET, UK
}

\begin{abstract}
The Jumbo flying squid Dosidicus gigas has a short life span and is subject to rapid changes in population size. This species inhabits the Eastern Pacific, one of the most variable oceanic environments in the world, subject to the El Niño Southern Oscillation (ENSO). This study examined the influence of environmental variability on squid abundance off Peru using mesoscale oceanographic indicators derived from remotely sensed satellite imagery. In the fishery area off Peru, squid abundance was positively associated with sea surface temperatures (SST) between 17 and $22^{\circ} \mathrm{C}$ during July, corresponding to the peak of the fishery season. In the putative hatching area close to the Costa Rica Dome, squid abundance was positively associated with SST of between 24 and $28^{\circ} \mathrm{C}$ during September, prior to the start of the fishery season. Squid abundance is apparently strongly influenced by mesoscale variability linked to ENSO, with low levels of upwelling during the very strong El Niño of 1997 to 1998 leading to very low catches of squid off Peru. Variability in upwelling off Peru and in the Costa Rica Dome region may drive primary and secondary production and transport processes affecting the planktonic early life stages and also the availability of food and suitable habitat for adult squid.
\end{abstract}

KEY WORDS: Costa Rica Dome - Dosidicus gigas - El Niño Southern Oscillation - Eastern Pacific · Fishery $\cdot$ Flying squid $\cdot$ Mesoscale oceanography $\cdot$ Upwelling

\section{INTRODUCTION}

The Jumbo flying squid Dosidicus gigas has a widespread distribution throughout the Eastern Pacific between $40^{\circ} \mathrm{N}$ and $47^{\circ} \mathrm{S}$ (Nesis 1983, Nigmatullin et al. 2001), with occasional catches made further north (to $45^{\circ} \mathrm{N}$ ) possibly linked to El Niño events (Pearcy 2002). This species supports the largest cephalopod fishery in the region, with both commercial and artisanal fleets operating off the coasts of Peru, Mexico (Gulf of California), Central America and Chile (Yamashiro et al. 1998, Nevárez-Martínez et al. 2000, Ichii et al. 2002, Rocha \& Vega 2003). Since the early 1990s, there has been an increase in industrial vessels, largely from Eastern Asia (Japan and Korea), fishing off Peru, with a resulting increase in squid catches from this region. As in many commercially important species of ommas- trephid squid (Waluda et al. 1999, Dawe et al. 2000, Sakurai et al. 2000, Yatsu et al. 2000), the population of D. gigas shows large fluctuations in abundance from year to year (Yamashiro et al. 1998, Rodhouse 2001, Taipe et al. 2001), and catches off Peru were highly variable during the 1990s with a high of $164000 \mathrm{t}$ in 1994 and a low of $0.6 \mathrm{t}$ in 1998.

The Eastern Pacific is a region of complex surface oceanography, consisting of 2 low-velocity eastern boundary currents, the Peru (Humboldt) and California currents, flowing north and south respectively along the continental margins of North and South America. Both regions are areas of strong coastal upwelling characterised by numerous fronts, eddies and meanders (Longhurst 1998). Under normal conditions and periods of cooling (La Niña), upwelling is related to well developed easterly trade winds, a shal- 
lower thermocline, the upwelling of cool, nutrient-rich waters, and high primary productivity (Barber \& Chavez 1983, Carr et al. 2002). During warming (El Niño) events, the trade winds weaken and are replaced by westerlies at low latitudes (Longhurst 1998). In addition, the thermocline is depressed and upwelling consists of nutrient-depleted waters, such that productivity is reduced (Barber \& Chavez 1983, Huyer et al. 1987). At the equator, 3 currents arise, the westward-flowing North and South Equatorial Currents, and the eastward-flowing Equatorial Counter Current, which bifurcates as it nears the continental margin, giving rise to the Costa Rica Dome. The Dome is an area where the generally strong and shallow thermocline of the eastern tropical Pacific becomes even shallower, with cold nutrient-rich water occurring close to the surface (Wyrtki 1964, Fiedler 2002). This is an area of high productivity, with a regional maximum in chlorophyll concentration in surface waters from

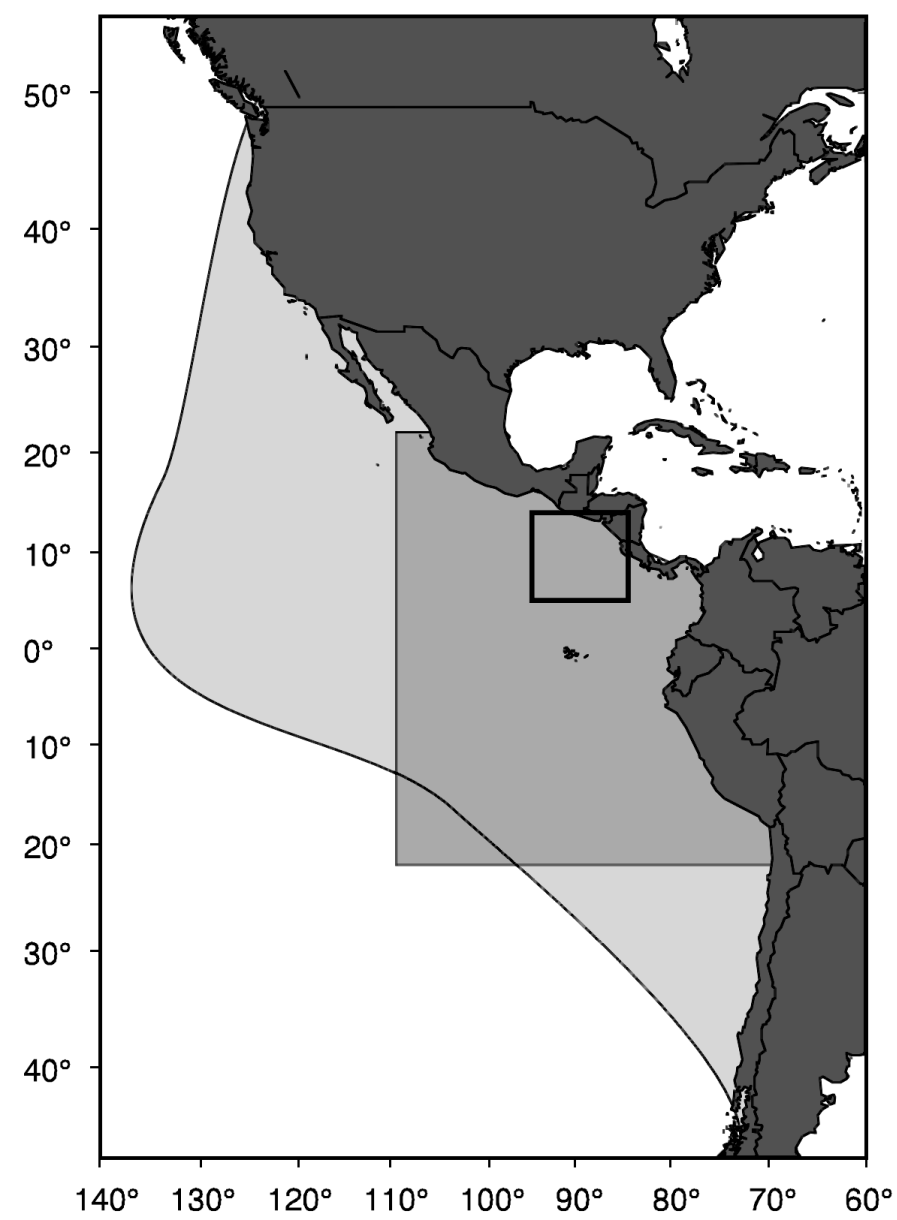

Fig. 1. Eastern Pacific. Medium grey shading indicates Dosidicus gigas fishery area, with box indicating location of putative hatching area. Light grey region shows approximate limits of the species distribution
May to September, and an associated high abundance of zooplankton (Fiedler 2002).

Dosidicus gigas is a eurythermic species, with a usual temperature range of between 15 and $28^{\circ} \mathrm{C}$ (Nesis 1983), although squid have been found to tolerate extremes of between 4 and $32^{\circ} \mathrm{C}$ in the deep ocean and equatorial waters respectively (Nigmatullin et al. 2001). The highest concentrations of squid have been recorded at temperatures of between 24 and $29^{\circ} \mathrm{C}$ in the northern hemisphere (Nesis 1983, Vecchione 1999, Nevárez-Martínez et al. 2000, Ichii et al. 2002), and between 17 and $23^{\circ} \mathrm{C}$ in the southern hemisphere (Nesis 1983, Yamashiro et al. 1998, Taipe et al. 2001, Waluda et al. 2006). In common with the majority of squid species, D. gigas has a life span of around $1 \mathrm{yr}$ (Nesis 1983, Nigmatullin et al. 2001), which means that the population size is not damped by multiple age classes, and responds rapidly to changes in environmental conditions (Rodhouse 2001, Jackson \& Domier 2003). Sea surface temperature (SST) per se does not appear to be directly related to squid abundance in the Eastern Pacific (Nevárez-Martínez et al. 2000, Ichii et al. 2002, Waluda et al. 2006), but may provide a useful proxy for mesoscale processes influencing squid abundance, such as variability in Peru Current upwelling (Waluda et al. 2006).

Previous work has shown that the population of Dosidicus gigas is influenced by environmental variability mediated by El Niño and La Niña during both the juvenile (Anderson \& Rodhouse 2001) and adult (Ichii et al. 2002, Waluda et al. 2006) life-history stages, and also by the associated Southern Oscillation Index (SOI) and Trans Polar Index (TPI) during the juvenile and adult life history stages respectively (Waluda et al. 2004). In this study, the use of satellite-derived mesoscale oceanographic indices as proxies for environmental variability was examined, based on defined SST limits in (1) the fishery region off the coast of Peru (Nigmatullin et al. 2001, Taipe et al. 2001), and (2) the putative hatching area (Anderson \& Rodhouse 2001, Waluda et al. 2006) off the coast of Costa Rica (Fig. 1). The influence of this mesoscale oceanographic variability on the abundance of $D$. gigas was investigated over the period 1991 to 2001, which included significant La Niña and El Niño events during 1996 and 1998 to 1999 respectively (Fig. 2). Temperatures between 17 and $22^{\circ} \mathrm{C}$ were defined as 'favourable for fishery aggregations' (Waluda et al. 2006), and temperatures between 24 and $28^{\circ} \mathrm{C}$ were defined as 'favourable for hatching and development' based on artificial fertilisation experiments by Ichii et al. (2002). Each environmental indicator was compared with the abundance of squid during the period of the fishery (Year $n$ ) and the year prior to the fishery (Year $n-1$ ) to examine influences on the adult and juvenile life history stages respectively. 


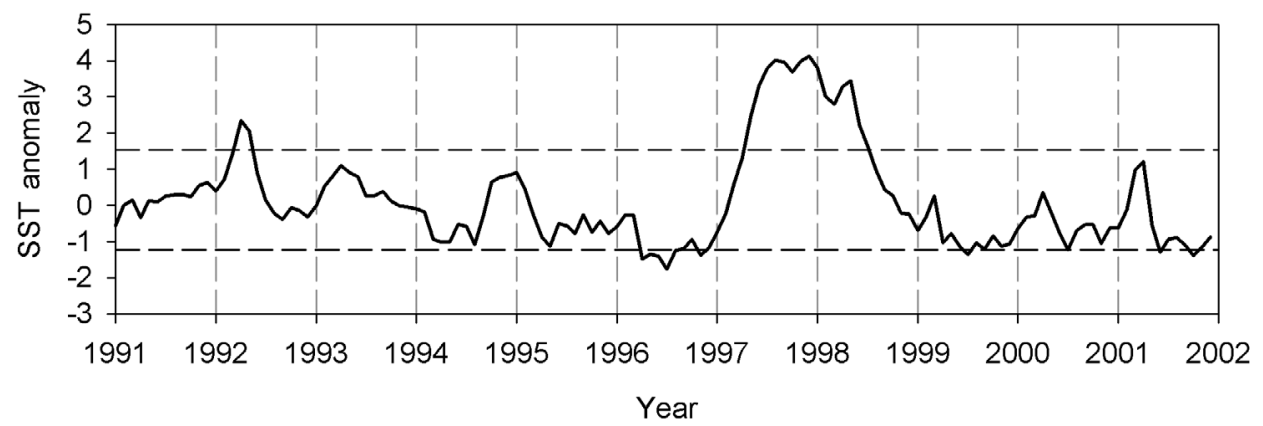

Fig. 2. Sea surface temperature (SST) anomalies, 1991 to 2001, for El Niño Area 1+2. Horizontal dashed lines indicate \pm 1 SD

\section{MATERIALS AND METHODS}

Data sources. Fishery data: Data on catch (tonnes) and effort (hours fished) were obtained for the commercial jigging fleet operating off the coast of Peru (Fig. 3). Data were obtained on an annual basis for the period 1991 to 2001 from the Instituto del Mar del Perú (IMARPE), Callao, Peru.

Environmental data: Monthly data on SST from the Eastern Pacific (El Niño Area 1+2, consisting of mean monthly SST for the region between 0 and $10^{\circ} \mathrm{S}, 80$ and $90^{\circ} \mathrm{W}$ ) were obtained from the National Oceanic and Atmospheric Administration (NOAA) National Weather Service Climate Prediction Center for the period January 1991 to December 2000 (Fig. 2; www. cpc.ncep.noaa.gov/data/indices/index.html).

Remotely sensed sea surface temperature data: Remotely sensed SST data were obtained from the Rosenstiel School of Marine and Atmospheric Science (RSMAS), Miami. Data comprised 7-day composite advanced very high resolution radiometer (AVHRR) imagery, at a spatial resolution of $4 \times 4 \mathrm{~km}$ for the period January 1991 to December 2000. Composite images were made in order to minimise cloud coverage, by assigning each cell the warmest SST observed from all single-pass images available in each $7 \mathrm{~d}$ period. For each month of the period January 1991 to December 2000, a single composite image was obtained from the database (120 satellite images in total). All images were incorporated into a Geographic Information System (GIS; Arc Info Version 8.3, ESRI, Environmental Systems Research Institute). We derived 2 environmental indicators based on the putative optimal environment for (1) adult squid and (2) hatching and development of eggs and juveniles (see following subsections).

Analyses. Environmental indicators as proxies for ENSO: Regression analysis was used to examine the use of each of the 2 environmental indicators as proxies for ENSO variability. Monthly anomalies (deviation from the monthly mean) for each environmental indi- cator (see following subsections) were compared with SST anomaly data for El Niño Area 1+2 for the period January 1991 to December 2000.

SST favourable for fishery aggregations (17 to $22^{\circ} \mathrm{C}$ ): The fishery region was defined as the area of the Pacific between $20^{\circ} \mathrm{N}$ and $20^{\circ} \mathrm{S}$, coastal margins to $110^{\circ} \mathrm{W}$, consistent with the central part of the species distribution (Nigmatullin et al. 2001 and our Fig. 1). For each image, SST values in the range of 17 to $22^{\circ} \mathrm{C}$ were extracted and defined as temperatures favourable for fishery aggregations i.e. 'fishery-favourable SST' $^{\prime}$ (consistent with Nesis 1983, Yamashiro et al. 1998, Taipe et al. 2001, Waluda et al. 2006). Fishery data (annual catch per unit effort, CPUE) were compared with data describing the proportion of the fishery area occupied by SST between 17 and $22^{\circ} \mathrm{C}$ (by month, January to December) for the season prior to recruitment (Year $\mathrm{n}-1$ ) and during the period of recruitment into the fishery (Year $\mathrm{n}$ ), to examine effects on juvenile and adult life history stages respectively.

SST favourable for hatching and development (24 to $28^{\circ} \mathbf{C}$ ): The hatching region was defined as 5 to $14^{\circ} \mathrm{N}$, 85 to $95^{\circ} \mathrm{W}$ (Fig. 1) based on the location of the Costa Rica Dome (putative spawning area; see Anderson \&

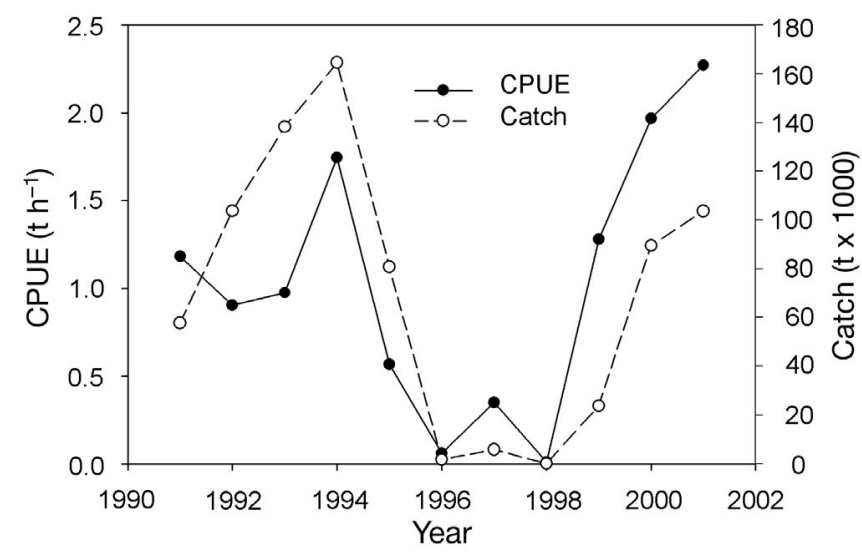

Fig. 3. Dosidicus gigas. Annual catch per unit effort (CPUE) and yearly catch in Peruvian waters, 1991 to 2001 

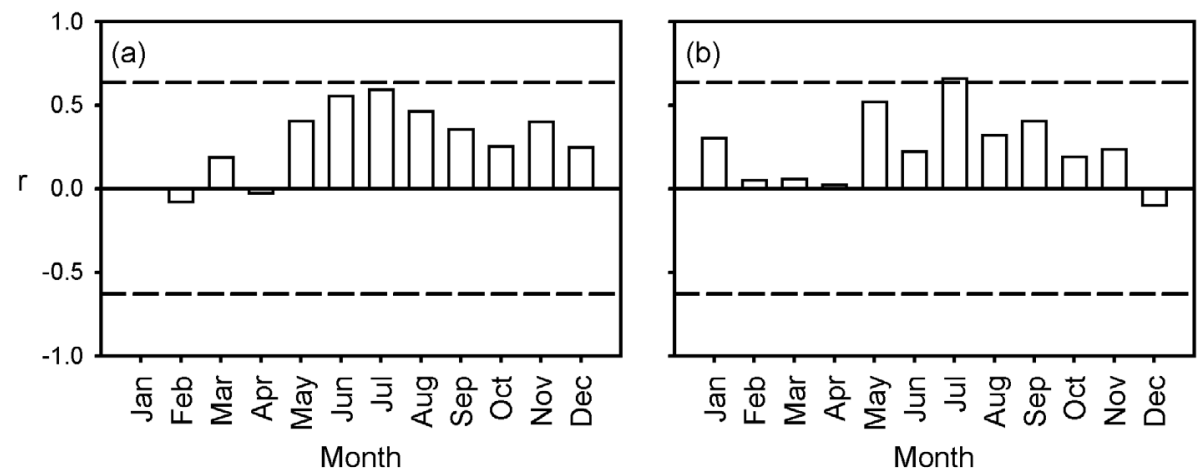

Fig. 4. Dosidicus gigas. Correlation (r-values) between catch per unit effort (CPUE) and 'favourable' $\mathrm{SST}$ (17 to $\left.22^{\circ} \mathrm{C}\right)$ in fishery area off Peru during (a) the season prior to recruitment and (b) the fishery period. Dashed horizontal lines indicate probability levels of $\mathrm{p}<0.05$

Rodhouse 2001, Waluda et al. 2006), the location of high abundances of ommastrephid paralarvae (likely to be Dosidicus gigas) reported by Vecchione (1999), and the location of mated females reported by Ichii et al. (2002). For each SST image, pixels with an SST value of between 24 and $28^{\circ} \mathrm{C}$ were extracted, and defined as 'hatching-favourable $\mathrm{SST}^{\prime}$ based on artificial fertilisation experiments by Ichii et al. (2002). The proportion of the putative hatching area occupied by waters of favourable SST was calculated for each image. Fishery data (annual CPUE) were compared with data on the proportion of the putative hatching area occupied by SST between 24 and $28^{\circ} \mathrm{C}$ (by month, January to December) for the season prior to recruitment (Year $n-1$ ) and during the period of recruitment into the fishery (Year $\mathrm{n}$ ) in order to examine effects on juvenile and adult life history stages respectively.

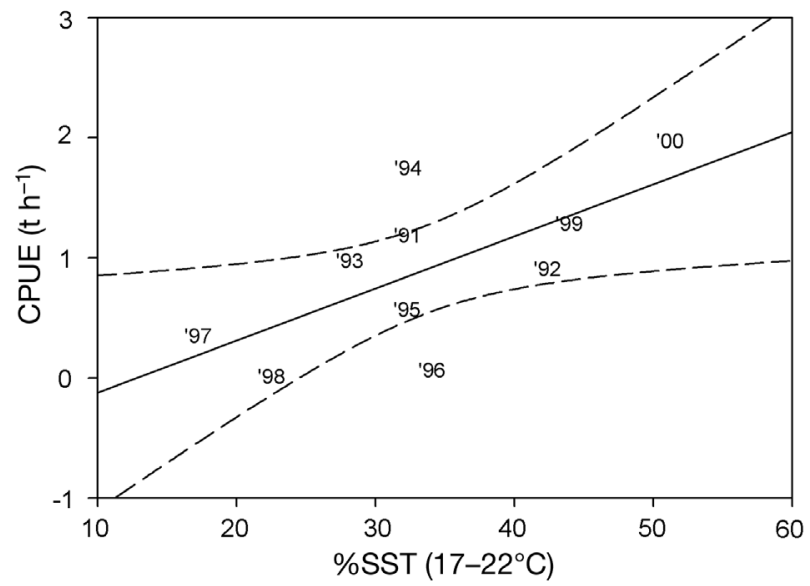

Fig. 5. Dosidicus gigas. Catch per unit effort (CPUE) in Peruvian waters (1991 to 2000) versus proportion of study area occupied by SST between 17 and $22^{\circ} \mathrm{C}$ (i. e. favourable for fishery aggregations) during July of the fishery season. Continuous line: regression line, CPUE $=-0.555+0.0434 \times$ SST $\left(R^{2}=0.43\right)$; dashed lines: $95 \%$ confidence intervals

\section{RESULTS}

\section{Environmental indicators as proxies for ENSO}

Regression analysis suggested that fisheryfavourable SST anomalies $\left(17\right.$ to $22^{\circ} \mathrm{C}$ ) were negatively related to SST anomalies for El Niño Area 1+2 (n = 120, $\left.F_{1,119}=90.74, \mathrm{R}^{2}=0.44, \mathrm{p}<0.001\right)$ such that high levels of fishery-favourable SST were related to a decrease in SST anomalies (cooling) in El Niño data. Hatchingfavourable SST anomalies in the putative hatching area were also negatively related to SST anomalies for El Niño Area $1+2\left(\mathrm{n}=120, F_{1,119}=140.34, \mathrm{R}^{2}=0.54\right.$, $\mathrm{p}<0.001)$.

\section{SST favourable for fishery aggregations $\left(17\right.$ to $\left.22^{\circ} \mathrm{C}\right)$}

The proportion of the study region occupied by fishery-favourable waters varied between 0 and $70 \%$ per month between January 1991 and December 2000. Regression analysis suggested no significant correlation between fishery-favourable SST in the season prior to recruitment and the abundance of Dosidicus gigas (annual CPUE) (Fig. 4a). However, squid abundance was positively related to the proportion of the study region occupied by waters with SST between 17 and $22^{\circ} \mathrm{C}$ during July of the fishery period (Fig. 4b) (n = 10; $F_{1,9}=6.10 ; \mathrm{R}^{2}=0.44 ; \mathrm{p}<$ 0.05; 1991 to 2000; Fig. 5). A higher abundance of squid was associated with higher levels of fisheryfavourable SST waters, whereas lower squid abundance was related to lower levels of fisheryfavourable waters. During July, areas with SST of 17 to $22^{\circ} \mathrm{C}$ were generally observed between the equator and $20^{\circ} \mathrm{S}$, with the area occupied varying between $17 \%$ (1997) and $51 \%$ (2000). 

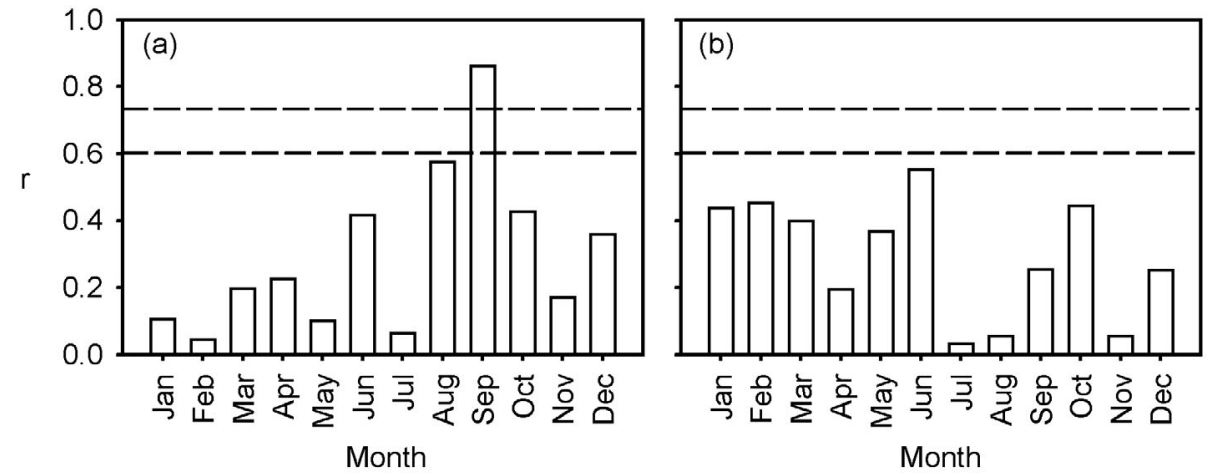

Fig. 6. Dosidicus gigas. Correlation (r-values) between catch per unit effort (CPUE) and 'hatching-favourable' SST (24 to $\left.28^{\circ} \mathrm{C}\right)$ in putative spawning area off Costa Rica Dome during (a) the season prior to recruitment and (b) the fishery period. Dashed horizontal lines indicate probability levels of $\mathrm{p}<0.05$ and $<0.001$

\section{SST favourable for hatching and development $\left(24\right.$ to $\left.28^{\circ} \mathrm{C}\right)$}

The proportion of the putative hatching area occupied by hatching-favourable SST $\left(24\right.$ to $28^{\circ} \mathrm{C}$ ) varied between 6 and $96 \% \mathrm{mo}^{-1}$ between January 1991 and December 2000. Regression analyses suggested that the abundance of Dosidicus gigas was strongly related to hatching-favourable SST in September prior to the start of the fishing season (Fig. 6a) ( $\mathrm{n}=10 ; F_{1,9}=23.08$; $\mathrm{R}^{2}=0.743, \mathrm{p}<0.01 ; 1991$ to 2000; Fig. 7). No significant correlations were found between hatching-favourable SST and CPUE during the fishery period (Fig. 6b). Higher squid abundance was related to higher levels of hatching-favourable SST in the previous year, and lower abundance was related to lower levels of hatching-favourable SST. Areas with SST between 24 and $28^{\circ} \mathrm{C}$ were generally observed north of the equator, with occasional incursions into southern regions (to around $12^{\circ} \mathrm{S}$ ), during periods of El Niño (especially 1997). The proportion of the putative hatching area occupied by hatching-favourable SST varied between $53 \%$ (1991) and 80\% (2000) during September prior to the start of the fishing season.

\section{DISCUSSION}

Mesoscale oceanographic indicators derived from satellite remote sensing appear to be useful proxies for describing the effects of the El Niño Southern Oscillation (ENSO) off the coast of Peru, with the 2 indices apparently operating out of phase with ENSO events. Higher levels of fishery-favourable SST (17 to $22^{\circ} \mathrm{C}$ ) were observed during periods of cooling (La Niña), possibly linked to an increase in upwelling. Higher levels of hatching-favourable SST $\left(24\right.$ to $\left.28^{\circ} \mathrm{C}\right)$ in the putative hatching area were also observed during periods of cooling, and it is possible that El Niño (warming events) could cause a displacement of hatching-favourable SST out of the hatching region. Patterns in mesoscale variability are more likely to be indicative of local environmental processes, compared with larger scale SST or ENSO data, and may provide insights into processes such as variability in food availability and the availability of suitable conditions or habitat favouring high squid abundance.

An increase in fishery-favourable SST (17 to $22^{\circ} \mathrm{C}$ ) during July was associated with an increase in annual squid catches off the coast of Peru during the period 1991 to 2000. Higher catches were observed in the fishery, when fishery-favourable waters occupied a wide area offshore of Peru. Lower catches were

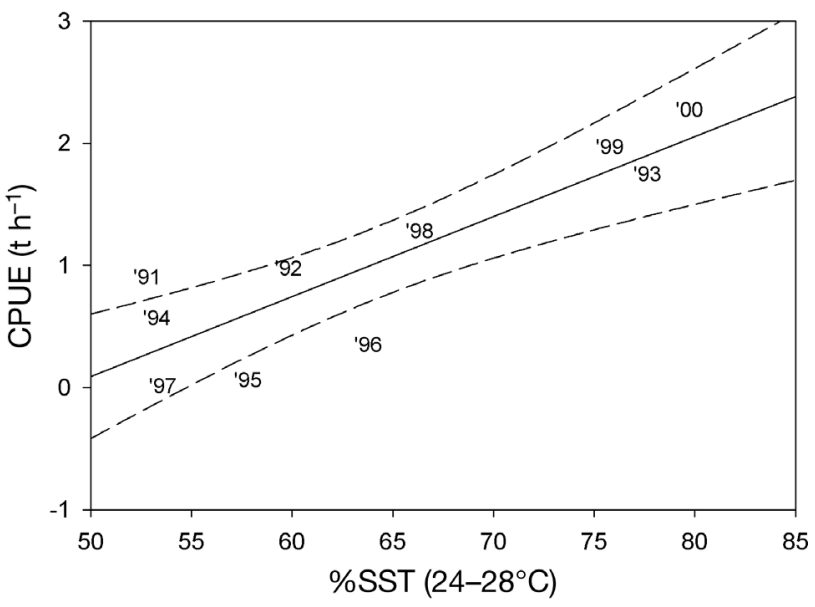

Fig. 7. Dosidicus gigas. Catch per unit effort (CPUE) $\left(\mathrm{t} \mathrm{h}^{-1}\right)$ in Peruvian waters (1991 to 2000) vs. proportion of putative hatching region occupied by SST between 24 and $28^{\circ} \mathrm{C}$ (favourable for hatching) in September prior to start of the fishing season. Continuous line: regression line, CPUE = $-3.18+0.0655 \times$ SST $\left(R^{2}=0.74\right)$; dashed lines: $95 \%$ confidence intervals. Year labels on regression lines correspond to relevant SST years 
observed when fishery-favourable water was displaced to the south away from the coast. An increase in fishery-favourable waters reflects an overall reduction in SST off Peru and is likely to indicate an increase in the upwelling of cool, nutrient-rich waters. It is probable that variability in upwelling and primary productivity rather than variability in temperature per se is a key factor in influencing the abundance of adult Dosidicus gigas in the Eastern Pacific (Waluda et al. 2006). Patterns of chlorophyll variability off South America have been shown to closely track surfacetemperature patterns, so SST is likely to be a reasonable proxy for productivity in the region (Thomas et al. 2001); however, data on levels of chlorophyll and factors such as sea level and wind direction should be taken into account (Nixon \& Thomas 2001, Carr et al. 2002) in further investigations of links between squid abundance and upwelling variability.

At the most simple level, an increase in squid abundance is likely to be supported by an increase in prey species such as fishes (particularly myctophids), copepods, hyperiid amphipods, euphausiids, pelagic shrimp and the red crab Pleuroncodes planipes (Nigmatullin et al. 2001), linked to increased primary and secondary productivity. Levels of phytoplankton and zooplankton off Peru have been shown to be higher during periods of cooler (increased upwelling) conditions (Alheit \& Niquen 2004, Ayón et al. 2004), which could potentially support higher numbers of planktivorous species such as myctophid fishes. In addition, a reduction, or shift in distribution of predatory species could favour higher survival of squid in this region. For example, species such as yellowfin tuna Thunnus albacares that prey on subadult squid (Nigmatullin et al. 2001) have been shown to decline off Peru during periods of cooling (Chavez et al. 2003). Sperm whales Physeter macrocephalus are major predators of Dosidicus gigas in the Eastern Pacific (Clarke \& Paliza 2001) and variations in their movement patterns and behaviour have been shown to be related to changes in squid abundance in the Gulf of California (Jaquet et al. 2003). During periods of strong trade winds, and hence increased upwelling, squid in the Eastern Pacific are generally larger and mature later (Nigmatullin et al. 2001), potentially leading to larger catches of squid off Peru. Any or all of these factors could be responsible for improving squid abundance off Peru during periods of increased fishery-favourable SST.

SST in the range of 17 to $22^{\circ} \mathrm{C}$ does not appear to influence the abundance of squid during the early life history stages, despite significant spawning off the coast of Peru (Tafur et al. 2001). In the putative hatching area of the Costa Rica Dome, an increase in hatching-favourable SST $\left(24\right.$ to $28^{\circ} \mathrm{C}$ ) was associated with an increase in squid catches in the following year. Higher squid abundance in the Peruvian fishery was associated with an increase in hatching-favourable SST during September prior to the start of the fishery. This is reasonably consistent with the observed hatching period (October) for squid in this region (Ichii et al. 2002). It is likely that higher levels of hatchingfavourable SST may be indicative of a well developed Costa Rica Dome, which tends to form during July to November (Fiedler 2002).

Increased upwelling in the vicinity of the Costa Rica Dome and a well developed countercurrent thermocline ridge is likely to be responsible for the accumulation of adult squid, including mated females (Ichii et al. 2002) and the retention of paralarvae (Vecchione 1999) in a region favourable for hatching and development. Favourable reproductive habitat tends to be associated with food enrichment, concentrated patch structure, and flow mechanisms that enable the population to maintain itself as a cohesive unit (Bakun \& Csirke 1998), all of which are fulfilled by the Costa Rica Dome system. The oceanography of the spawning and hatching region, and particularly an association between paralarvae and frontal regions has been shown to be important in influencing recruitment in a number of ommastrephid species, e.g. Todarodes pacificus paralarvae show high abundance to the north of the Kuroshio front (Bower et al. 1999), Illex illecebrosus are associated with the Gulf Stream front (Rowell \& Trites 1985), and I. argentinus with the Brazil Current front (Waluda et al. 2001).

El Niño and La Niña events are likely to influence the size and position of the Costa Rica Dome (Fiedler 2002), and thus the area available for spawning and development. The highest levels of hatchingfavourable SST were observed during 1993, 1999 and 2000, corresponding to normal and cooler years, and potentially a larger and more productive Costa Rica Dome (Fiedler 2002). In addition, female squid dominated hand-jigged catches in this region (>90\% of the catch), with mated females more abundant during the La Niña of 1999 (27 of 180 individuals; $15 \%$ ) than during the El Niño of 1997 (4 of 83 individuals; 5\%) (Ichii et al. 2002) and subsequently higher catches in the Peru fishery during 2000 compared to 1998.

The size and position of the Costa Rica Dome shows a high level of intra- and inter-annual variability (Fiedler 2002), so the timing of spawning and the subsequent probability of retention of paralarvae are very important in sustaining a viable population. In addition, other spawning events off the coast of Peru are likely to supply the Peruvian fishery (Tafur et al. 2001), and levels of predation by mammals, fishes and cephalopods (including cannibalism) are a further complication to be taken into account when examining links between spawning events and recruitment. 
Variability in the environment of the putative hatching area has an apparent affect on the abundance of squid in the Peru fishery, suggesting that a central resident population of Dosidicus gigas based close to the Costa Rica Dome could provide a mechanism for the dispersal of squid to the north and south (Nigmatullin et al. 2001, Waluda et al. 2006). The population structure of $D$. gigas is unclear, but the hypothesis is further supported by a positive relationship between squid catches in the Gulf of California (Santa Rosalía; Moralez-Bojorquez et al. 2001) and hatching-favourable SST in the putative hatching area in April prior to the start of the fishery $\left(\mathrm{n}=10, F_{1,9}=9.29, \mathrm{R}^{2}=0.54\right.$, $\mathrm{p}<0.05$; C. M. Waluda unpubl. data).

Increased upwelling and higher primary productivity in both the spawning area close to the Costa Rica Dome and fishery area off Peru appears to have supported the largest fisheries in this region over the last decade. Dosidicus gigas exhibits latitudinally separated spawning and feeding areas, which is typical of ommastrephid squid (Waluda et al. 2004). This life cycle is likely to have evolved to take advantage of seasonal productivity patterns, with hatching taking place in warmer areas (close to the equator) and feeding in cooler more productive high- to mid-latitude regions (O'Dor 1992). Conditions favourable for $D$. gigas appear to correspond to the cool anchovy regime (La Vieja) described by Chavez et al. (2003), characterised by a lower sea level, shallower thermocline, increased nutrient supply and increased productivity in the Eastern Pacific. In addition, catch data from FAO suggest similar patterns of variability in catches of anchovy Engraulis ringens and D. gigas over the previous decade (1990 to 2002) (FAO 2000). It appears that D. gigas, as well as responding to ENSO variability, may be an additional indicator of regime change in the Eastern Pacific, and further analysis is required as the fishery time-series is extended.

Data derived from remote sensing can be readily used to create testable hypotheses that can be further examined using GIS and field studies, and the use of environmental indices as proxies for complex processes can be used to examine links between mesoscale oceanography and recruitment success. The results obtained herein provide a basis for further analysis, particularly in examining the influence of upwelling on Dosidicus gigas fisheries throughout the Eastern Pacific, and in locating other likely spawning areas.

Acknowledgements. Support from the British Antarctic Survey (Natural Environmental Research Council) is gratefully acknowledged. Thanks to N. J. Cunningham and A. G. Wood for help with satellite data-processing, and to P. N. Trathan and 4 anonymous referees for valuable comments and advice on an earlier draft. Thanks also to C. Yamashiro from the Instituto del Mar del Perú (IMARPE) for support of this work and supplying the fishery data, and to G. P. Podestá and V. Halliwell from the Rosenstiel School of Marine and Atmospheric Sciences, Miami, for their interest in this work and supplying the satellite SST data. This research is funded under the British Antarctic Survey's 'Antarctic Science in the Global Context' Programme.

\section{LITERATURE CITED}

Alheit J, Niquen M (2004) Regime shifts in the Humboldt Current ecosystem. Prog Oceanogr 60:201-222

Anderson CIH, Rodhouse PG (2001) Life cycles, oceanography and variability: ommastrephid squid in variable oceanographic environments. Fish Res 54:133-143

Ayón P, Purca S, Guevara-Carrasco R (2004) Zooplankton volume trends off Peru between 1964 and 2001. ICES J Mar Sci 61:478-484

Bakun A, Csirke J (1998) Environmental processes and recruitment variability. FAO Fish Tech Pap 376:105-124

Barber RT, Chavez FP (1983) Biological consequences of El Niño. Science 222:1203-1210

Bower JR, Nakamura Y, Mori K, Yamamoto J, Isoda Y, Sakurai Y (1999) Distribution of Todarodes pacificus (Cephalopoda: Ommastrephidae) paralarvae near the Kuroshio off southern Kyushu, Japan. Mar Biol 135: 99-106

Carr ME, Strub PT, Thomas AC, Blanco JL (2002) Evolution of 1996-1999 La Niña and El Niño conditions off the western coast of South America: a remote sensing perspective. J Geophys Res 107 (C12), 3236, doi:10.1029/2001JC 001183

Chavez FP, Ryan J, Lluch-Cota SE, Ñiquen CM (2003) From anchovies to sardines and back: multidecadal change in the Pacific Ocean. Science 299:217-221

Clarke R, Paliza O (2001) The food of sperm whales in the southeast Pacific. Mar Mamm Sci 17:427-429

Dawe EG, Colbourne EB, Drinkwater KF (2000) Environmental effects on recruitment of short-finned squid (Illex illecebrosus). ICES J Mar Sci 57:1002-1013

FAO (Food and Agriculture Organisation) (2000) Fishstat plus: universal software for fishery statistical time series. FAO Fisheries Department, Fishery Information, Data and Statistics Unit, Rome

Fiedler PC (2002) The annual cycle and biological effects of the Costa Rica Dome. Deep-Sea Res I 49:321-338

Huyer A, Smith RL, Paluszkiewicz T (1987) Coastal upwelling off Peru during normal and El Niño times, 1981-1984. J Geophys Res I 92:14297-14307

Ichii $T$, Mahapatra $K$, Watanabe $T$, Yatsu A, Inagake D, Okada Y (2002) Occurrence of jumbo flying squid Dosidicus gigas aggregations associated with the countercurrent ridge off the Costa Rica Dome during 1997 El Niño and 1999 La Niña. Mar Ecol Prog Ser 231:151-166

Jackson GD, Domier ML (2003) The effects of an extraordinary El Niño/La Niña event on the size and growth of the squid Loligo opalescens off Southern California. Mar Biol 142:925-935

Jaquet N, Gendron D, Coakes A (2003) Sperm whales in the Gulf of California: residency, movements, behavior, and the possible influence of variation in food supply. Mar Mamm Sci 19:545-562

Longhurst AR (1998) Ecological geography of the sea. Academic Press, San Diego

Moralez-Bojorquez E, Cisneros-Mata MA, Nevárez-Martinez 
MO, Hernández-Herrera A (2001) Review of stock assessment and fishery biology of Dosidicus gigas in the Gulf of California, Mexico. Fish Res 54:83-94

Nesis KN (1983) Dosidicus gigas. In: Boyle PR (ed) Cephalopod life cycles, Vol 1. Academic Press, London, p 215-231

Nevárez-Martínez MO, Hernández-Herrera A, MoralesBojórquez E, Balmori-Ramírez A, Cisneros-Mata MA, Morales-Azpeitia R (2000) Biomass and distribution of the jumbo squid (Dosidicus gigas; d'Orbigny, 1835) in the Gulf of California, Mexico. Fish Res 49:129-140

Nigmatullin CM, Nesis KN, Arkhipkin AI (2001) A review of the biology of the jumbo squid Dosidicus gigas (Cephalopoda: Ommastrephidae). Fish Res 54:9-19

Nixon S, Thomas AC (2001) On the size of the Peru upwelling ecosystem. Deep-Sea Res I 48:2521-2528

O'Dor RK (1992) Big squid in big currents. S Afr J Mar Sci 12: 225-235

Pearcy WG (2002) Marine nekton off Oregon and the 1997-1998 El Niño. Prog Oceanogr 54:399-403

Rocha F, Vega MA (2003) Overview of cephalopod fisheries in Chilean waters. Fish Res 60:151-159

Rodhouse PG (2001) Managing and forecasting squid fisheries in variable environments. Fish Res 54:3-8

Rowell TW, Trites RW (1985) Distribution of larval and juvenile Illex (Mollusca: Cephalopoda) in the Blake Plateau region (Northwest Atlantic). Vie Milieu 35:149-161

Sakurai Y, Kiyofuji H, Saitoh S, Goto T, Hiyama Y (2000) Changes in inferred spawning areas of Todarodes pacificus (Cephalopoda: Ommastrephidae) due to changing environmental conditions. ICES J Mar Sci 57:24-30

Tafur R, Villegas P, Rabi N, Yamashiro C (2001) Dynamics of maturation, seasonality of reproduction and spawning grounds of the jumbo squid Dosidicus gigas (Cephalopoda: Ommastrephidae) in Peruvian waters. Fish Res 54:33-50

Taipe A, Yamashiro C, Mariátegui L, Rojas P, Roque C (2001) Distribution and concentrations of jumbo flying squid (Dosidicus gigas) off the Peruvian coast between 1991 and

Editorial responsibility: Otto Kinne (Editor-in-Chief), Oldendorf/Luhe, Germany
1999. Fish Res 54:21-32

Thomas AC, Blanco JL, Carr ME, Strub PT, Osses J (2001) Satellite-measured chlorophyll and temperature variability off northern Chile during the 1996-1998 La Niña and El Niño. J Geophys Res 106:899-915

Vecchione M (1999) Extraordinary abundance of squid paralarvae in the tropical Eastern Pacific Ocean during El Niño of 1987. Fish Bull 97:1025-1030

Waluda CM, Trathan PN, Rodhouse PG (1999) Influence of oceanographic variability on recruitment in the Illex argentinus (Cephalopoda: Ommastrephidae) fishery in the South Atlantic. Mar Ecol Prog Ser 183:159-167

Waluda CM, Rodhouse PG, Podestá GP, Trathan PN, Pierce GJ (2001) Surface oceanography of the inferred hatching grounds of Illex argentinus (Cephalopoda: Ommastrephidae) and influences on recruitment variability. Mar Biol 139:671-679

Waluda CM, Trathan PN, Rodhouse PG (2004) Synchronicity in southern hemisphere squid stocks and the influence of the Southern Oscillation and Trans Polar index. Fish Oceanogr 13:255-266

Waluda CM, Yamashiro C, Rodhouse PG (2006) Influence of the ENSO cycle on the light-fishery for Dosidicus gigas in the Peru Current: an analysis of remotely sensed data. Fish Res (in press)

Wyrtki K (1964) Upwelling in the Costa Rica Dome. Fish Bull 63:355-372

Yamashiro C, Mariátegui L, Rubio J, Arguelles J, Tafur R, Taipe A, Rabí M (1998) Jumbo flying squid fishery in Peru. In: Okutani T (ed) Large pelagic squids. Japan Marine Fishery Resources Research Center, Tokyo, p 119-125

Yatsu A, Watanabe T, Mori J, Nagasawa K, Ishida Y, Meguro T, Kamei Y, Sakurai Y (2000) Interannual variability in abundance of the neon flying squid, Ommastrephes bartramii, in the North Pacific Ocean during 1979-1998: impact of driftnet fishing and oceanographic conditions. Fish Oceanogr 9:163-170

Submitted: January 14, 2005; Accepted: September 19, 2005 Proofs received from author(s): February 21, 2006 